\title{
The SOX2 Status of Disseminated Tumor Cells in Breast Cancer Patients Treated With Neoadjuvant Chemotherapy
}

\author{
NATALIA KRAWCZYK ${ }^{1}$, KATHRIN JANOWSKI ${ }^{2}$, MAGGIE BANYS-PALUCHOWSKI ${ }^{3,4}$, \\ ANNETTE STAEBLER ${ }^{5}$, HANS NEUBAUER ${ }^{1}$, CHRISTOPH MEISNER ${ }^{6}$, \\ ANDREAS HARTKOPF ${ }^{2}$, SARA BRUCKER ${ }^{2}$, DIETHELM WALLWIENER ${ }^{2}$ and TANJA FEHM ${ }^{1}$ \\ ${ }^{1}$ Department of Obstetrics and Gynecology, University of Duesseldorf, Duesseldorf, Germany; \\ ${ }^{2}$ Department of Obstetrics and Gynecology, University of Tuebingen, Tuebingen, Germany; \\ ${ }^{3}$ Department of Obstetrics and Gynaecology, University Hospital Schleswig-Holstein, Campus Lübeck, Lübeck, Germany; \\ ${ }^{4}$ Medical Faculty, University of Duesseldorf, Duesseldorf, Germany; \\ ${ }^{5}$ Department of Pathology, University of Tuebingen, Tuebingen, Germany; \\ ${ }^{6}$ Institute for Clinical Epidemiology and Applied Biometry, University of Tuebingen, Tuebingen, Germany
}

\begin{abstract}
Background/Aim: Detection of disseminated tumor cells (DTCs) after systemic treatment predicts poor prognosis in breast cancer patients. The aim of our study was to assess the expression of stem-cell marker SOX2 on DTCs and in the primary tumor of patients treated with neoadjuvant chemotherapy (NAT). Materials and Methods: In 170 DTCpositive patients after NAT an additional slide of bone marrow aspirate was stained by double immunofluorescence to detect SOX2-positive DTCs. The SOX2 status of the primary tumor was assessed using the same antibody. Results: The SOX2-status of DTCS was determined in 62 patients and 20 of those (32\%) had SOX2 positive DTCs. The SOX2 status of DTCs was not associated with any of the clinicopathological factors. A total of $36 \%$ of the patients with a SOX2-negative tumor showed SOX2-positive persistent DTCs. Conclusion: SOX2-positive DTCs can be detected in breast cancer patients after NAT, even in patients with SOX2negative primary tumors. This suggests that these populations may have evolved independently of each other.
\end{abstract}

In the past decade, neoadjuvant therapy (NAT) has become a standard approach in breast cancer (BC) management and is recommended if chemotherapy is indicated based on

This article is freely accessible online.

Correspondence to: Dr. Natalia Krawczyk, MD, Department of Obstetrics and Gynaecology, University of Duesseldorf, Moorenstr. 5, 40225 Duesseldorf, Germany. Tel: +49 0211/8117501, Fax: +49 0211/8118483,e-mail: Natalia.krawczyk@med.uni-duesseldorf.de

Key Words: Breast cancer stem cells, minimal residual disease, SOX2, neoadjuvant treatment, persistent disseminated tumor cells. clinical characteristics and tumor subtype (1). The original aim of NAT was to reduce the size of inoperable or large tumors, thus allowing complete surgical removal and, in some cases, breast conservation (2). However, potential advantages of NAT reach beyond tumor size reduction and include in vivo evaluation of tumor sensitivity and identification of non-responders, who can be spared of the unnecessary toxicity of ineffective therapy $(3,4)$. Moreover, residual tumor burden after NAT is an indicator of unfavourable outcome in most subtypes of $\mathrm{BC}$ and may guide the choice of further post-neoadjuvant treatment strategies $(5,6)$.

While NAT can induce a pathological complete response (pCR) in up to $60 \%$ of BC patients, predicting the long-term survival benefit, a relevant proportion of $\mathrm{BC}$ patients still suffer from distant recurrence during follow up (6). The presumed pathophysiology of metastatic relapse is based on an early haematogenous spread of cells from the primary tumor. These isolated tumor cells can be detected in peripheral blood (circulating tumor cells, CTCs) or bone marrow (BM) (disseminated tumor cells, DTCs) of patients with most solid malignancies. In breast cancer, presence of CTCs and DTCs has been confirmed as an independent unfavourable prognostic factor for overall survival (OS) and disease-free survival (DFS) (7-11). CTCs/DTCs are nowadays assumed to be a surrogate marker for minimal residual disease (MRD) and their eradication is one of key goals of systemic treatment in non-metastatic BC $(12,13)$. Since DTCs can persist in secondary homing sites after completion of cytotoxic treatment, their further characterisation aiming at identifying new therapeutic targets is of high clinical interest.

There is a growing body of evidence that tumor progression and metastasis formation can be traced to a small subpopulation of tumor cells with stem-like features, usually 
referred to as cancer stem cells (CSCs) $(14,15)$. Several studies have shown that these cancer-initiating or stem-like cells persist beyond treatment with cytotoxic agents, suggesting the development of effective mechanisms of chemoresistance (16-19). In this context, it has been hypothesized that at least some DTCs are in fact CSCs. Several studies reported that DTCs with stem-like phenotypes can be detected in the BM of primary BC patients (20-22). Moreover, the presence of stem-like DTCs was shown to predict unfavourable prognosis (22). However, the stem-like features of DTCs persisting beyond neoadjuvant chemotherapy have been scarcely investigated so far $(21,22)$.

Sex-determining region Y (SRY)-Box2 (SOX2) is a key member of the SOX transcription factor family and an essential embryonic stem cell marker able to induce pluripotency in human somatic cells $(23,24)$. An important role of SOX2 as a stem cell marker in different human malignancies including breast cancer has been reported previously (25-29). A high expression of SOX2 has also been demonstrated in breast cancer cells that have acquired chemoresistance (30). The aim of this study was to assess the expression of SOX2 in DTCs persistent after NAT in a large cohort of patients with primary non-metastatic breast cancer and to compare it with clinicopathological factors as well as the SOX2 status of the primary tumor.

\section{Patients and Methods}

A total of 170 primary breast cancer patients treated from 2001 to 2011 at the Department of Obstetrics and Gynecology, University of Tuebingen, Germany were eligible for this analysis. Nonmetastatic BC (T1-T4, N0-3, M0) patients, who received intraoperative BM biopsy and were DTC-positive after completion of NAT were included into the study. Patients with history of any malignancy were excluded. This study was approved by the Ethical Committee of the University of Tuebingen (307/2012R). Patient characteristics are shown in Table I. Pathological complete response (pCR) was defined as the absence of residual invasive cancer in the breast and negative lymph node status after NAT (ypT0/ypTis ypN0). The flow chart of the study is shown in Figure 1.

Collection and analysis of bone marrow. Between 10 and $20 \mathrm{ml}$ of $\mathrm{BM}$ were aspirated intraoperatively from the anterior iliac crest under general anaesthesia and processed within 24 hours. All specimens were obtained after written informed consent from patients. This study was approved by the local ethical committee (307/2012R). BM samples were separated by density centrifugation over Ficoll (Biochrom, Germany) with a density of $1.077 \mathrm{~g} / \mathrm{ml}$. If necessary, red blood cells were lysed with lysis buffer $(155 \mathrm{mM} \mathrm{NH} 4 \mathrm{Cl}, 10 \mathrm{mM}$ $\mathrm{KHCO}_{3}, 0.1 \mathrm{mM}$ EDTA pH 7.2). Using a cytocentrifuge (Hettich, Tuttlingen, Germany), $1 \times 10^{6}$ mononuclear cells were spun onto a glass slide and dried at the room temperature, overnight. For each patient, $2 \times 10^{6}$ cells were analyzed and the remaining slides were stored at $-20^{\circ} \mathrm{C}$. Slides were than fixed in a $0.5 \%$ neutral buffered formalin solution for $10 \mathrm{~min}$ and were rinsed in phosphate-buffered saline. Automatic immunostaining was performed on the DAKO autostainer using the monoclonal mouse A45-B/B3 Pan-cytokeratin antibody (Micromet, Munich, Germany), and the DAKO-APAAP detection kit (DakoCytomation, Glostrup, Denmark) according to the manufacturers' instructions. Slides were automatically scanned using the ACIS ${ }^{\text {TM }}$ imaging system (ChromaVision, Medical Systems Inc., San Juan, Capistrano, CA, USA) and evaluated based on the recommendations for standardized tumor cell detection as described previously $(31,32)$. In a subset of DTC-positive patients one additional slide per patient was analysed by immunofluorescence double staining for the presence of SOX2-positive DTCs $\left(1 \times 10^{6}\right.$ cells per patient). Control cytospins with SOX2-positive HT-29 cells were prepared, stored and fixed in the same way.

Immunofluorescence staining of SOX2. One additional slide was thawed at room temperature in a humid chamber for approximately $20 \mathrm{~min}$. After an initial washing step with PBS (Sigma, Munich, Germany), cells were permeabilized with $0.1 \%$ Triton X-100 for 12 min and after being washed three times, blocked with normal donkey serum (Santa Cruz Biotechnology, Santa Cruz, CA, USA) at a 1:10 dilution for $30 \mathrm{~min}$. The automated double immunofluorescence staining procedure was performed on the DAKO Autostainer using the polyclonal goat Sox2-antibody (R\&D Systems, Inc., Minneapolis, MN, USA) at a 1:50 dilution for 60 min. Cytospins were simultaneously incubated with fluorescein isothiocyanate (FITC) conjugated pan-cytokeratin antibody (C11) (1:500, Sigma, Munich, Germany) for $30 \mathrm{~min}$. Secondary detection was performed with a donkey anti-goat antibody, labelled with Alexa Fluor 594 (1:400, Invitrogen Molecular Probes, Carlsbad, CA, USA) for $30 \mathrm{~min}$. Vectashield mounting medium with DAPI (Vector Laboratories, Burlingame, CA, USA) was used to stain nuclei. Preparations of the colorectal cancer cell line HT-29 mixed with PBMCs from a healthy volunteer served as a positive control for CK and SOX2 staining. For the SOX2 negative control, all conditions were kept the same, except that the primary antibody was omitted. Additionally, cytospins of PBMCs with no added tumor cells served as a negative control for both. Positive and negative control staining is demonstrated in Figure 2.

Fluorescence microscopy. Slides were manually analysed for the presence of tumor cells using a computerised fluorescence microscope Axioplan 2 ( $\times 40$ oil immersion objectives, Carl Zeiss Micro Imaging GmbH, Göttingen, Germany). To screen for SOX2positive DTCs a single-pass filter for individual fluorochromes, FITC, Texas Red or DAPI, and a triple-pass filter for (FITC/TRITC/DAPI) were used. Immunostained cells were evaluated based on the morphological criteria of the International Society of Hematotherapy and Graft Engineering Working group for standardisation of tumor cell detection and the consensus statements $(33,34)$. Cytokeratin-positive cells that contained an intact nucleus (DAPI positive) were identified as DTCs. DTCs with either moderate or intense staining of the nucleus were considered SOX2 positive. Slides were evaluated by two, or in doubtful cases, three independent investigators (TF, KJ and $\mathrm{HN}$ ).

Immunohistochemical staining of the primary tumor. Immunohistochemical analysis was performed either on core biopsies or surgical resection specimens according to the method described previously by our group (35). Staining was performed on 3 to $5 \mu \mathrm{m}$ thick sections using DAB Map Detection Kit and heat-induced antigen retrieval (HIER). The polyclonal goat SOX2 antibody (R\&D Systems, Inc.) was diluted 1:40 in DISCOVERY Antibody Diluent 
Table I. Clinical data of all patients included into the trial.

\begin{tabular}{|c|c|}
\hline & $\begin{array}{c}\mathrm{n} \\
\mathrm{N}=170(\%)\end{array}$ \\
\hline Total & 170 \\
\hline \multicolumn{2}{|l|}{ Menopausal status } \\
\hline Premenopausal & $86(51)$ \\
\hline Postmenopausal & $84(49)$ \\
\hline \multicolumn{2}{|c|}{ Tumour size before NAT } \\
\hline $\mathrm{cT} 1$ & $2(1)$ \\
\hline $\mathrm{cT} 2$ & $82(48)$ \\
\hline cT3 & $43(25)$ \\
\hline cT4 & $38(22)$ \\
\hline unknown & $5(3)$ \\
\hline \multicolumn{2}{|c|}{ Tumor size after NAT } \\
\hline ypT0/ypTis & $44(26)$ \\
\hline ypT1 & $66(39)$ \\
\hline урT2-4 & $60(35)$ \\
\hline \multicolumn{2}{|c|}{ Nodal status before NAT } \\
\hline Negative & $49(29)$ \\
\hline Positive & $117(69)$ \\
\hline Unknown & $4(2)$ \\
\hline \multicolumn{2}{|c|}{ Nodal status after NAT } \\
\hline ypN0 & $89(52)$ \\
\hline $\mathrm{ypN}+$ & $81(48)$ \\
\hline \multicolumn{2}{|c|}{ Pathologic response } \\
\hline $\mathrm{pCR}$ & $38(22)$ \\
\hline non-pCR & $132(78)$ \\
\hline \multicolumn{2}{|l|}{ Histology } \\
\hline Ductal & $141(83)$ \\
\hline Lobular & $26(15)$ \\
\hline Others & $3(2)$ \\
\hline \multicolumn{2}{|l|}{ Grading } \\
\hline $\mathrm{I} / \mathrm{II}$ & $114(67)$ \\
\hline III & $56(33)$ \\
\hline \multicolumn{2}{|l|}{ ER status } \\
\hline Negative & $73(43)$ \\
\hline Positive & $97(57)$ \\
\hline \multicolumn{2}{|l|}{ PR status } \\
\hline Negative & $46(27)$ \\
\hline Positive & $124(73)$ \\
\hline \multicolumn{2}{|l|}{ HER2 status } \\
\hline Negative & $133(78)$ \\
\hline Positive & $37(22)$ \\
\hline \multicolumn{2}{|l|}{ IHC subtype } \\
\hline HR+/HER2- & $92(54)$ \\
\hline $\mathrm{HR}+/ \mathrm{HER} 2+$ & $19(11)$ \\
\hline HR-/HER2+ & $18(11)$ \\
\hline TNBC & $41(24)$ \\
\hline
\end{tabular}

ER: Estrogen receptor; HER2: human epidermal growth factor receptor 2; PR: progesterone receptor; IHC: immunohistochemistry; TNBC: triple negative breast cancer, NAT: neoadjuvant treatment; pCR: pathological complete response.

(Ventana) and applied according to the manufacturer's instructions. Secondary detection was performed with a rabbit anti-goat antibody (Jackson ImmunoResearch, Inc., West Grove, PA, USA) at a 1:200 dilution. 3,3'diaminobenzidine (DAB) was used as a chromogen Finally, the slides were counterstained with haematoxylin and

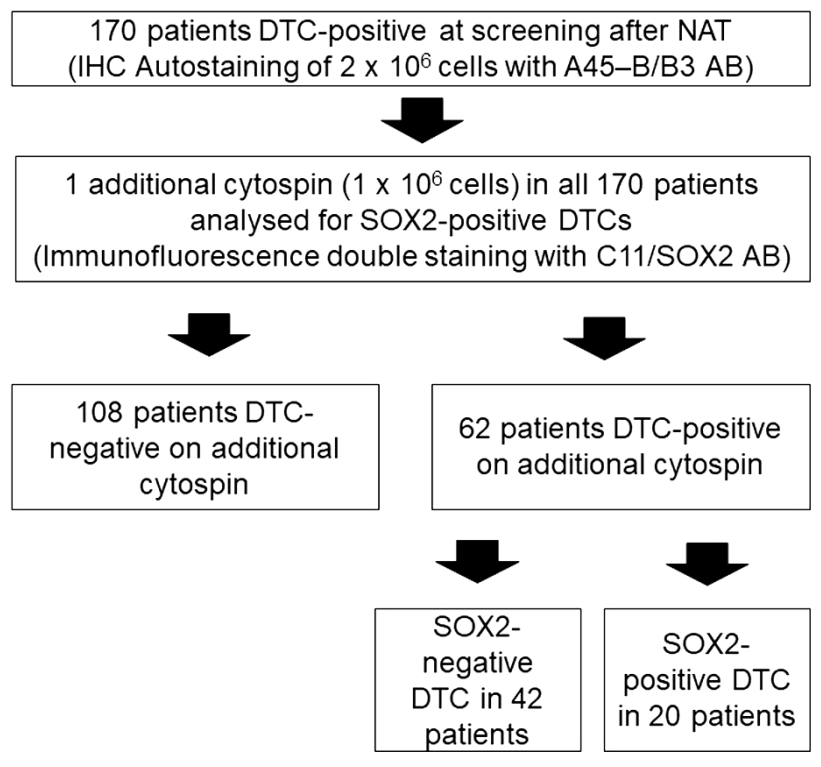

Figure 1. Study flow chart. DTC: Disseminated tumor cell, AB: antibody, IHC: immunocytochemistry, NAT: neoadjuvant therapy.

mounted for examination. For assessment of the SOX2 status, the percentage of cells with nuclear reactivity (score 0 : none, $1:>0 \%$ $<10 \%, 2:>10 \%<50 \%, 3: \geq 50 \%<90 \%, 4: \geq 90 \%$ ) was determined according to the score published by Pham et al. (36). Tumors with a score of 1 or more were considered SOX2 positive.

Statistical analysis. A chi-squared test was used to evaluate the relation between SOX2-positive DTCs and/or primary tumor and clinicopathological factors. Statistical analysis was performed by SPSS, version 24 (SPSS Inc., Chicago, IL, USA). Values of $p<0.05$ were considered statistically significant.

\section{Results}

Patients' characteristics. A total of 170 primary BC patients were included in the analysis. The clinical data of patients are listed in Table I. 86 out of 170 (51\%) patients were premenopausal. The most common histological tumor type was invasive ductal carcinoma $(83 \%)$. Estrogen and progesterone receptor (ER, PR) status were positive in $57 \%$ and $73 \%$ of these patients, respectively. 37 patients $(22 \%)$ had HER2-positive tumors. All patients were treated with NAT. 38 out of 170 (22\%) patients achieved pathological complete response (pCR).

SOX2 status of DTCs after NAT. SOX2 status of persistent DTCs was determined in 62 patients after NAT. Among these 62 patients, SOX2-positive DTCs were detected in 20 cases (32\%; Table II, Figure 3). No significant correlation was observed between SOX2 status of DTCs and any 


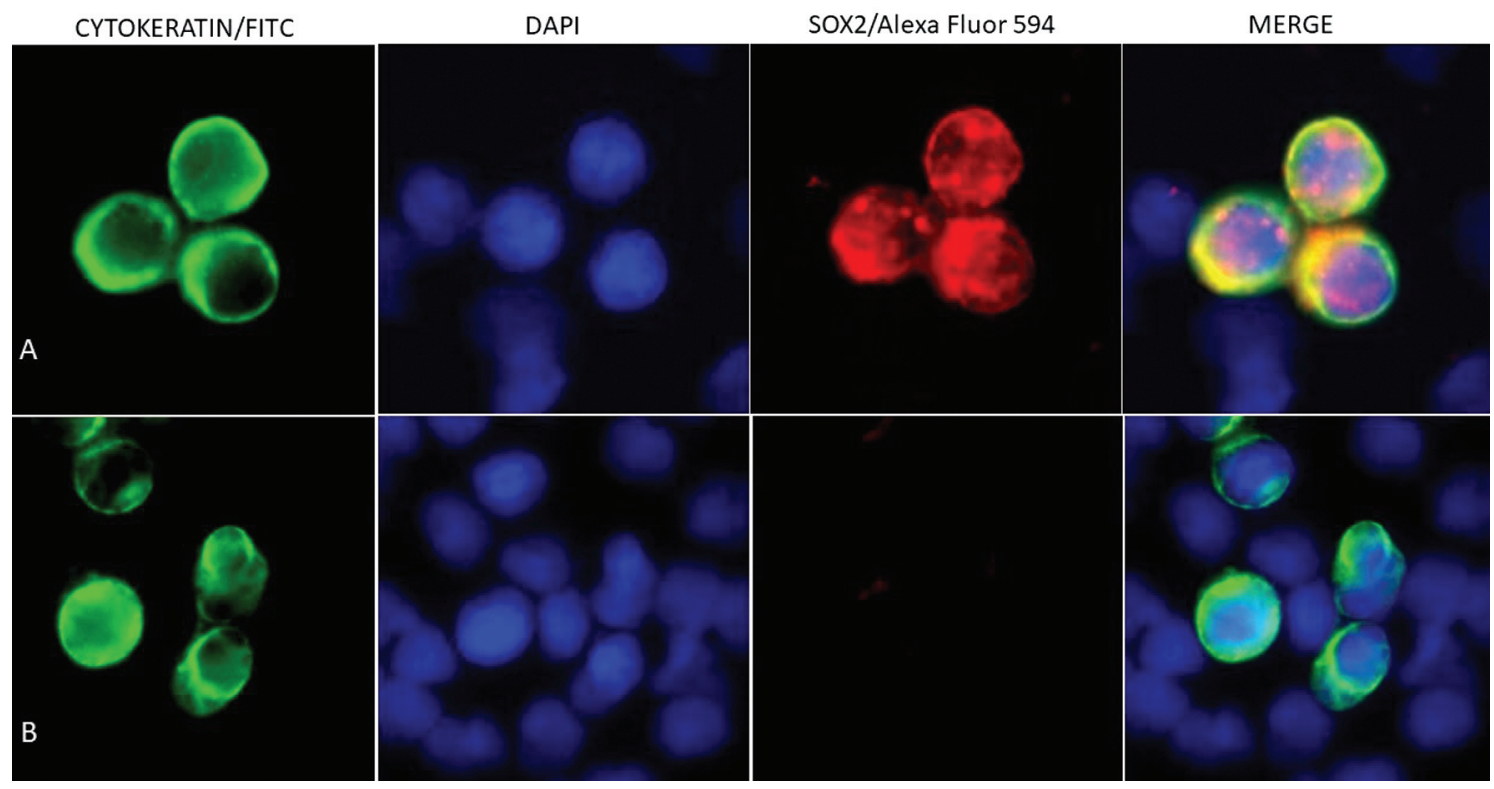

Figure 2. SOX2 control staining. (A) Positive control staining (HT-29 cells). (B) Negative control staining (HT-29 cells, primary antibody omitted) ( $\times 63$ oil immersion objective).

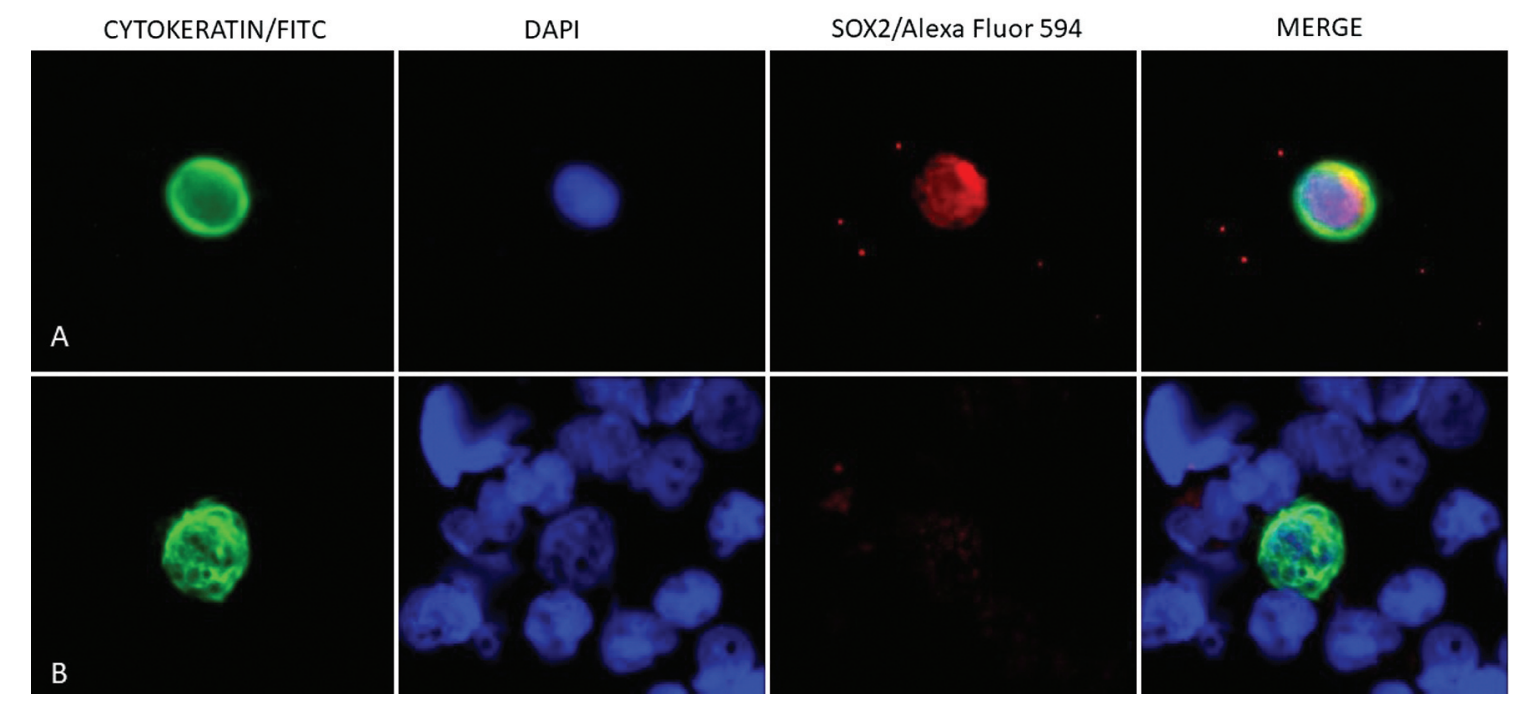

Figure 3. SOX2 staining of DTCs in primary breast cancer patients. (A) SOX2-positive DTC. (B) SOX2-negative DTC (x63 oil immersion objective).

clinicopathological characteristics. SOX2 status of DTCs persisting beyond NAT was not associated with pathological response to treatment.

Expression of SOX2 in the primary tumor. Primary tumor tissue was available for immunohistochemical determination of SOX2 status in 38 patients prior to systemic treatment and in 27 patients after NAT. The tumors were SOX2-negative in most cases [30 out of $38(79 \%)$ before and 18/27 (67\%) after NAT, respectively]. No correlation could be found between the SOX2 status of primary tumor (pre- and posttherapeutic) and any of the established prognostic factors. Neither was the SOX2 status of primary tumor associated with response to NAT. In 17 patients, the SOX2 status has been assessed on persistent DTCs and the primary tumor 
Table II. Clinical data of 62 patients included in further analysis of SOX2-status of DTC.

\begin{tabular}{|c|c|c|c|}
\hline & $\mathrm{n}(\%)$ & $\begin{array}{l}\text { SOX2-positive } \\
\text { DTCs }(\%)\end{array}$ & $p$-Value* \\
\hline Total & $62(100)$ & $20(32)$ & \\
\hline Menopausal status & & & 1.0 \\
\hline Premenopausal & $31(50)$ & $10(32)$ & \\
\hline Postmenopausal & $31(50)$ & $10(32)$ & \\
\hline Tumor size before NAT & & & 0.76 \\
\hline cT1 & $1(2)$ & $0(0)$ & \\
\hline $\mathrm{cT} 2$ & $27(43)$ & $8(30)$ & \\
\hline cT3 & $13(21)$ & $6(46)$ & \\
\hline cT4 & $18(29)$ & $5(28)$ & \\
\hline unknown & $3(5)$ & $1(33)$ & \\
\hline Tumor size after NAT & & & 0.45 \\
\hline урT0/ypTis & $16(26)$ & $4(25)$ & \\
\hline урТ1 & $24(39)$ & $10(42)$ & \\
\hline урT2-4 & $22(35)$ & $6(27)$ & \\
\hline Nodal status before NAT & & & 0.94 \\
\hline Negative & $14(23)$ & $4(29)$ & \\
\hline Positive & $45(73)$ & $15(33)$ & \\
\hline Unknown & $3(5)$ & $1(33)$ & \\
\hline Nodal status after NAT & & & 0.47 \\
\hline ypN0 & $30(48)$ & $11(37)$ & \\
\hline $\mathrm{ypN}+$ & $32(52)$ & $9(28)$ & \\
\hline Pathologic response & & & 0.55 \\
\hline $\mathrm{pCR}$ & $12(19)$ & $3(15)$ & \\
\hline non-PCR & $50(81)$ & $17(27)$ & \\
\hline Histology & & & 0.53 \\
\hline Ductal & $52(84)$ & $18(35)$ & \\
\hline Lobular & $8(13)$ & $2(25)$ & \\
\hline Others & $2(3)$ & $0(0)$ & \\
\hline Grading & & & 0.95 \\
\hline $\mathrm{I} / \mathrm{II}$ & $40(65)$ & $13(32)$ & \\
\hline III & $22(35)$ & $7(32)$ & \\
\hline ER status & & & 0.79 \\
\hline Negative & $20(32)$ & $6(30)$ & \\
\hline Positive & $42(68)$ & $14(33)$ & \\
\hline PR status & & & 0.59 \\
\hline Negative & $13(21)$ & $5(38)$ & \\
\hline Positive & 49 (79) & $15(31)$ & \\
\hline HER2 status & & & 0.36 \\
\hline Negative & $45(73)$ & $13(29)$ & \\
\hline Positive & 17 (37) & $7(41)$ & \\
\hline IHC subtype & & & 0.22 \\
\hline HR+/HER2- & $34(55)$ & $10(29)$ & \\
\hline HR+/HER2+ & $11(18)$ & $5(45)$ & \\
\hline HR-/HER2+ & $6(10)$ & $2(33)$ & \\
\hline TNBC & $11(18)$ & $3(27)$ & \\
\hline
\end{tabular}

*Chi-squared test. ER: Estrogen receptor; HER2: human epidermal growth factor receptor 2; PR: progesterone receptor; IHC: immunohistochemistry; TNBC: triple negative breast cancer; NAT: neoadjuvant treatment; pCR: pathological complete response.

before systemic treatment and showed a concordance rate of $59 \%$ (Table III). The SOX status of the primary tumor before and after NAT was evaluated in 18 patients and was concordant in $78 \%$ of cases ( $p=0.045$, Table IV).

\section{Discussion}

Disseminated tumor cells persisting beyond cytotoxic treatment predict impaired survival in primary breast cancer patients $(10,11,37)$. These cells are currently assumed to serve as a surrogate marker of minimal residual disease and their eradication is considered to be a main target of systemic therapy. However, about a half of DTC-positive BC patients remain tumor-free during a follow up period of over 10 years $(7,38)$. This phenomenon may be explained by the so-called "metastatic inefficiency". According to this hypothesis, only a small population of DTCs is able to persist and subsequently cause tumor growth in secondary sites $(39,40)$. One theory presently under discussion is the hypothesis that some of these cells undergo the process of epithelialmesenchymal transition (EMT) that increases their invasiveness and leads to acquisition of stem-cell features $(17,41,42)$. These cancer stem cells can evade systemic treatment and are thought to play a major role in the metastasis cascade $(18,42)$. In this context, we assessed the expression of the stem cell marker SOX2 on DTCs persisting in the BM of BC patients after NAT.

In 170 patients with persistent DTCs after completion of neoadjuvant therapy, an additional bone marrow cytospin was analyzed. In 62 cases, at least one DTC could be found and these patients were included in further analysis of the SOX2 status. Why some of the additional cytospins contained no DTCs can be explained by several factors, such as the freezing and thawing process of the slides, staining of only one additional slide $\left(1 \times 10^{6}\right.$ cells per patient $)$ compared to two slides $\left(2 \times 10^{6}\right.$ cells per patient) analyzed in the routine IHC staining as well as different assays (IHC vs. immunofluorescence) and the different anticytokeratin anibodies used (A45-B/B3 vs. C11).

To assess SOX2 status on persistent DTCs, we developed a double immunofluorescence staining assay based on cytokeratin positivity and morphological criteria according to the Consensus Recommendations for Standardized Tumor Cell Detection (34). 32\% of DTC-positive patients had at least one SOX2 positive tumor cell in BM. This is, to the best of our knowledge, the largest study demonstrating that DTCs persistent after NAT express a stem cell associated feature and the first evaluating SOX2 expression on DTCs in BC patients. Reuben et al. have analyzed DTCs in $30 \mathrm{BC}$ patients after NAT in terms of stemness and found epithelial CD44+CD24low cells in $57 \%$ of these patients (21). Similar to our observations, a detection of potential CSC in BM was not associated with response to NAT. In another study by Giordano et al., 18 of 26 patients (69\%) had potential CSCs in BM after NAT (22). The same detection method, a multiparameter flow cytometry, was used in both trials $(21,22)$ which might explain the much higher CSC positivity rates compared to our study. Further, both trials used 
Table III. SOX2 status of persistent DTCs and primary tumor before NAT.

\begin{tabular}{|c|c|c|c|c|}
\hline & \multirow[t]{2}{*}{ SOX2-status } & \multicolumn{2}{|c|}{ DTC } & \multirow[t]{2}{*}{ Total $(\%)$} \\
\hline & & SOX2 negative $(\%)$ & SOX2 positive (\%) & \\
\hline \multirow[t]{3}{*}{ PT } & SOX2 negative $(\%)$ & $9(53)$ & $5(29)$ & $14(82)$ \\
\hline & SOX2 positive (\%) & $2(12)$ & $1(6)$ & $3(18)$ \\
\hline & Total (\%) & $11(65)$ & $6(35)$ & $17(100)$ \\
\hline
\end{tabular}

PT: Primary tumor; DTC: disseminated tumor cell; NAT: neoadjuvant treatment.

Table IV. SOX2 status of the primary tumor before and after NAT.

\begin{tabular}{|c|c|c|c|c|}
\hline & \multirow[t]{2}{*}{ SOX2-status } & \multicolumn{2}{|c|}{ PT pre-NAT } & \multirow[t]{2}{*}{ Total $(\%)$} \\
\hline & & SOX2 negative $(\%)$ & SOX2 positive $(\%)$ & \\
\hline \multirow[t]{3}{*}{ PT post-NAT } & SOX2 negative (\%) & $11(61)$ & $3(17)$ & $14(78)$ \\
\hline & SOX2 positive (\%) & $1(5.6)$ & $3(17)$ & $4(22)$ \\
\hline & Total $(\%)$ & $12(66)$ & $6(34)$ & $18(100)$ \\
\hline
\end{tabular}

PT: Primary tumor; NAT: neoadjuvant treatment.

ALDH/CD44/CD24 and not SOX2 as CSC marker, making a direct comparison of our studies difficult.

Our analysis demonstrates that some of the cells detected in secondary homing sites after NAT may exhibit a stem-like phenotype. Tumor initiating-capacity on the one hand and ability to elude cytotoxic therapy and persist in a quiescent and/or dormant state on the other hand, are the features postulated to account for chemoresistance and metastatic potential of CSCs (43). A high expression of SOX2 has been indeed demonstrated in BC cell lines known for their crossresistance to taxanes, anthracyclines and cisplatin (30). Furthermore, SOX2 expression has been linked to tamoxifen resistance in BC (44) and was shown to significantly affect adhesion properties of BC cells (45). SOX2 was also recently shown to mediate proliferation and dissemination in lung cancer cells resistant to tyrosine kinase inhibitors (46). The CSC hypothesis is supported by the phenomenon of tumor cell dormancy, clinically well-known in BC patients, who can experience a relapse after a very long period, sometimes up to 25 years, without evidence of the disease $(47,48)$. In concordance with this clinical observation isolated tumor cells have been detected in the blood of asymptomatic BC patients up to 22 years after primary surgery (49). However, these persistent cells have not been analyzed in terms of stem cell-like features in any of the available studies.

While studies on the expression of SOX2 on DTCs are missing, data on the SOX2 expression in primary BC tissue have been reported previously $(35,50)$ In our cohort, $21 \%$ of patients have SOX2-positive tumors prior to NAT and $33 \%$ of tumors were SOX2-positive after NAT. This is in line with our earlier analysis demonstrating a SOX2 tumor positivity rate of $28 \%$ (24/86 patients) (35), compared to $16.7 \%$ (33/198 patients) reported by Rodriguez-Pinilla et al. (50). The fact that the SOX2 positivity rate of the primary tumor in our cohort was higher after NAT than prior to the systemic therapy is consistent with the reported phenomenon that CSC frequency increases in BC tissue after cytotoxic treatment $(18,51)$. Recently, chemotherapy was shown to induce BC stemness in a xenograft mouse model (52). A direct comparison of SOX2 status between pre- and posttherapeutic tumor tissue was possible in 18 patients (Table IV). In this group, the SOX2 status remained the same in most patients, with only one patient acquiring SOX2 positivity and three patients converting from positive to negative SOX2 status.

In $41 \%$ of analyzed patients, the SOX 2 status of primary tumor before NAT differed from the SOX2 status of persistent DTCs. A positive SOX2 status of DTCs was observed in $36 \%$ of patients (5 of 14 cases) with SOX2negative tumors (Table III). A discrepancy between tumor and (persistent) DTCs regarding other phenotypic features has been described in previous studies (53-55), showing that MRD cells may evolve independently from the primary tumor. This observation is consistent with the parallel tumor progression model proposed by Klein et al. (56). 
Another aspect evaluated in our study was the correlation of SOX2 status of primary tumors/DTCs and other clinicalpathological factors. Previously published studies reported a significant association between SOX2 positivity and higher grading, nodal positivity and poor prognosis (57-59). In contrast, no correlations were observed in our study, possibly due to the fact that the SOX2 status of both the tumor and DTCs was only available in a small proportion of patients.

\section{Limitations of our Study}

Even though DTC detection based on their epithelial and morphological features is considered standard, the lack of single-cell molecular analysis confirming tumor origin and SOX2-positivity of these cells at the genomic level may be considered a potential limitation of our study. Furthermore, analysis of a whole BM suspension (approx. 5-10 ml), aspirated from each patient instead of one cytospin with $1 \times 10^{6}$ cells per patient would possibly provide higher DTC numbers and result in higher numbers of DTCs available for analysis of the SOX2 status. Further trials implementing molecular characterization of single DTCs as well as analysis of other stem cell-associated markers are necessary to confirm the stem-like character and to establish the DTCs' clinical relevance.

\section{Conclusion}

In the present study, we demonstrated that DTCs with stemlike phenotype can persist after neoadjuvant treatment in a relevant number of breast cancer patients. SOX2-positive DTCs were detected in patients with SOX2-negative primary tumors, suggesting that these populations may have evolved independently of each other. Stem-like character of minimal residual disease should be further evaluated using molecular analyses in future studies.

\section{Conflicts of Interest}

The Authors declare that there are no conflicts of interest.

\section{Authors' Contributions}

NK performed the data analysis and drafted the manuscript; KJ performed the IF experiments and collected the data; MBP made a substantial contribution to interpretation of the data and helped to draft the manuscript; AS performed and evaluated the IHC experiments of the primary tumors; HN coordinated the study and reviewed the manuscript; TF designed the study, made substantial contributions to interpretation of the data and reviewed the manuscript; HA, BS, WD and MC were involved in interpretation of the data, drafting of the manuscript or revising it. All Authors read and approved the final manuscript.

\section{Availability of Data and Materials}

The data that support the findings of this study are available from the authors upon reasonable request and with permission from Tanja Fehm.

\section{References}

1 Ditsch N, Untch M, Kolberg-Liedtke C, Jackisch C, Krug D, Friedrich M, Janni W, Müller V, Albert US, Banys-Paluchowski M, Bauerfeind I, Blohmer JU, Budach W, Dall P, Diel I, Fallenberg EM, Fasching PA, Fehm T, Gerber B, Gluz O, Hanf V, Harbeck N, Heil J, Huober J, Kreipe HH, Kühn T, Kümmel S, Loibl S, Lüftner D, Lux M, Maass N, Moebus V, Mundhenke C, Park-Simon TW, Reimer T, Rhiem K, Rody A, Schmidt M, Schneeweiss A, Solbach C, Solomayer EF, Stickeler E, Thomssen C, Witzel I, Wöckel A and Thill M: AGO recommendations for the diagnosis and treatment of patients with locally advanced and metastatic breast cancer: update 2020. Breast Care (Basel) 15(3): 294-309, 2020. PMID: 32774225. DOI: $10.1159 / 000508736$

2 Kümmel S, Holtschmidt J and Loibl S: Surgical treatment of primary breast cancer in the neoadjuvant setting. Br J Surg 101(8): 912-924, 2014. PMID: 24838656. DOI: 10.1002/bjs.9545

3 Jones RL and Smith IE: Neoadjuvant treatment for early-stage breast cancer: opportunities to assess tumour response. Lancet Oncol 7(10): 869-874, 2006. PMID: 17012049. DOI: 10.1016/S1470-2045(06)70906-8

4 Schwartz GF, Hortobagyi GN, Masood S, Palazzo J, Holland R, Page D and Consensus Conference Committee: Proceedings of the consensus conference on neoadjuvant chemotherapy in carcinoma of the breast, April 26-28, 2003, Philadelphia, PA. Hum Pathol 35(7): 781-784, 2004. PMID: 15257539. DOI: 10.1016/j.humpath.2004.02.006

5 von Minckwitz G, Untch M, Blohmer JU, Costa SD, Eidtmann H, Fasching PA, Gerber B, Eiermann W, Hilfrich J, Huober J, Jackisch C, Kaufmann M, Konecny GE, Denkert C, Nekljudova V, Mehta K and Loibl S: Definition and impact of pathologic complete response on prognosis after neoadjuvant chemotherapy in various intrinsic breast cancer subtypes. J Clin Oncol 30(15): 1796-1804, 2012. PMID: 22508812. DOI: 10.1200/JCO.2011.38.8595

6 Cortazar P, Zhang L, Untch M, Mehta K, Costantino JP, Wolmark N, Bonnefoi H, Cameron D, Gianni L, Valagussa P, Swain SM, Prowell T, Loibl S, Wickerham DL, Bogaerts J, Baselga J, Perou C, Blumenthal G, Blohmer J, Mamounas EP, Bergh J, Semiglazov V, Justice R, Eidtmann H, Paik S, Piccart M, Sridhara R, Fasching PA, Slaets L, Tang S, Gerber B, Geyer CE Jr, Pazdur R, Ditsch N, Rastogi P, Eiermann W and von Minckwitz G: Pathological complete response and long-term clinical benefit in breast cancer: the CTNeoBC pooled analysis. Lancet 384(9938): 164-172, 2014. PMID: 24529560. DOI: 10.1016/S0140-6736(13)62422-8

7 Braun S, Vogl FD, Naume B, Janni W, Osborne MP, Coombes RC, Schlimok G, Diel IJ, Gerber B, Gebauer G, Pierga JY, Marth C, Oruzio D, Wiedswang G, Solomayer EF, Kundt G, Strobl B, Fehm T, Wong GY, Bliss J, Vincent-Salomon A and Pantel K: A pooled analysis of bone marrow micrometastasis in breast cancer. N Engl J Med 353(8): 793-802, 2005. PMID: 16120859. DOI: 10.1056/NEJMoa050434 
8 Rack BK, Schindlbeck C and Andergassen U: Use of circulating tumor cells (ctc) in peripheral blood of breast cancer patients before and after adjuvant chemotherapy to predict risk for relapse: The success trial. Asco annual meeting 2010. J Clin Oncol 28(15_suppl): 1003, 2010. DOI: 10.1200/jco.2010.28.15_suppl.1003

9 Rack B, Schindlbeck C, Jückstock J, Andergassen U, Hepp P, Zwingers T, Friedl TW, Lorenz R, Tesch H, Fasching PA, Fehm T, Schneeweiss A, Lichtenegger W, Beckmann MW, Friese K, Pantel K, Janni W and SUCCESS Study Group: Circulating tumor cells predict survival in early average-to-high risk breast cancer patients. J Natl Cancer Inst 106(5): dju066, 2014. PMID: 24832787. DOI: 10.1093/jnci/dju066

10 Janni W, Rack B, Schindlbeck C, Strobl B, Rjosk D, Braun S, Sommer H, Pantel K, Gerber B and Friese K: The persistence of isolated tumor cells in bone marrow from patients with breast carcinoma predicts an increased risk for recurrence. Cancer 103(5): 884-891, 2005. PMID: 15666325. DOI: 10.1002/cncr.20834

11 Mathiesen RR, Borgen E, Renolen A, Løkkevik E, Nesland JM, Anker G, Ostenstad B, Lundgren S, Risberg T, Mjaaland I, Kvalheim G, Lønning PE and Naume B: Persistence of disseminated tumor cells after neoadjuvant treatment for locally advanced breast cancer predicts poor survival. Breast Cancer Res 14(4): R117, 2012. PMID: 22889108. DOI: 10.1186/ bcr3242

12 Krawczyk N, Banys M, Hartkopf A, Hagenbeck C, Melcher C and Fehm T: Circulating tumour cells in breast cancer. Ecancermedicalscience 7: 352, 2013. PMID: 24066018. DOI: 10.3332/ecancer.2013.352

13 Banys M, Krawczyk N and Fehm T: The role and clinical relevance of disseminated tumor cells in breast cancer. Cancers (Basel) 6(1): 143-152, 2014. PMID: 24434543. DOI: $10.3390 /$ cancers6010143

14 Reya T, Morrison SJ, Clarke MF and Weissman IL: Stem cells, cancer, and cancer stem cells. Nature 414(6859): 105-111, 2001. PMID: 11689955. DOI: 10.1038/35102167

15 Al-Hajj M, Wicha MS, Benito-Hernandez A, Morrison SJ and Clarke MF: Prospective identification of tumorigenic breast cancer cells. Proc Natl Acad Sci U S A 100(7): 3983-3988, 2003. PMID: 12629218. DOI: 10.1073/pnas.0530291100

16 Calcagno AM, Salcido CD, Gillet JP, Wu CP, Fostel JM, Mumau MD, Gottesman MM, Varticovski L and Ambudkar SV: Prolonged drug selection of breast cancer cells and enrichment of cancer stem cell characteristics. J Natl Cancer Inst 102(21): 1637-1652, 2010. PMID: 20935265. DOI: 10.1093/jnci/djq361

17 Morel AP, Lièvre M, Thomas C, Hinkal G, Ansieau S and Puisieux A: Generation of breast cancer stem cells through epithelial-mesenchymal transition. PLoS One 3(8): e2888, 2008. PMID: 18682804. DOI: 10.1371/journal.pone.0002888

18 Creighton CJ, Li X, Landis M, Dixon JM, Neumeister VM, Sjolund A, Rimm DL, Wong H, Rodriguez A, Herschkowitz JI, Fan C, Zhang X, He X, Pavlick A, Gutierrez MC, Renshaw L, Larionov AA, Faratian D, Hilsenbeck SG, Perou CM, Lewis MT, Rosen JM and Chang JC: Residual breast cancers after conventional therapy display mesenchymal as well as tumorinitiating features. Proc Natl Acad Sci USA 106(33): 1382013825, 2009. PMID: 19666588. DOI: 10.1073/pnas.0905718106

19 Lawson JC, Blatch GL and Edkins AL: Cancer stem cells in breast cancer and metastasis. Breast Cancer Res Treat 118(2): 241-254, 2009. PMID: 19731012. DOI: 10.1007/s10549-0090524-9
20 Balic M, Lin H, Young L, Hawes D, Giuliano A, McNamara G, Datar RH and Cote RJ: Most early disseminated cancer cells detected in bone marrow of breast cancer patients have a putative breast cancer stem cell phenotype. Clin Cancer Res 12(19): 5615-5621, 2006. PMID: 17020963. DOI: 10.1158/1078-0432.CCR-06-0169

21 Reuben JM, Lee BN, Gao H, Cohen EN, Mego M, Giordano A, Wang X, Lodhi A, Krishnamurthy S, Hortobagyi GN, Cristofanilli M, Lucci A and Woodward WA: Primary breast cancer patients with high risk clinicopathologic features have high percentages of bone marrow epithelial cells with ALDH activity and CD44 $\square$ CD24lo cancer stem cell phenotype. Eur J Cancer 47(10): 1527-1536, 2011. PMID: 21334874. DOI: 10.1016/j.ejca.2011.01.011

22 Giordano A, Gao H, Cohen EN, Anfossi S, Khoury J, Hess K, Krishnamurthy S, Tin S, Cristofanilli M, Hortobagyi GN, Woodward WA, Lucci A and Reuben JM: Clinical relevance of cancer stem cells in bone marrow of early breast cancer patients. Ann Oncol 24(10): 2515-2521, 2013. PMID: 23798614. DOI: 10.1093/annonc/mdt223

$23 \mathrm{Yu}$ J, Vodyanik MA, Smuga-Otto K, Antosiewicz-Bourget J, Frane JL, Tian S, Nie J, Jonsdottir GA, Ruotti V, Stewart R, Slukvin II and Thomson JA: Induced pluripotent stem cell lines derived from human somatic cells. Science 318(5858): 19171920, 2007. PMID: 18029452. DOI: 10.1126/science. 1151526

24 Giorgetti A, Montserrat N, Aasen T, Gonzalez F, Rodríguez-Pizà I, Vassena R, Raya A, Boué S, Barrero MJ, Corbella BA, Torrabadella M, Veiga A and Izpisua Belmonte JC: Generation of induced pluripotent stem cells from human cord blood using OCT4 and SOX2. Cell Stem Cell 5(4): 353-357, 2009. PMID: 19796614. DOI: $10.1016 /$ j.stem.2009.09.008

25 Leis O, Eguiara A, Lopez-Arribillaga E, Alberdi MJ, HernandezGarcia S, Elorriaga K, Pandiella A, Rezola R and Martin AG: Sox 2 expression in breast tumours and activation in breast cancer stem cells. Oncogene 31(11): 1354-1365, 2012. PMID: 21822303. DOI: $10.1038 /$ onc .2011 .338

26 Chen Y, Shi L, Zhang L, Li R, Liang J, Yu W, Sun L, Yang X, Wang Y, Zhang Y and Shang Y: The molecular mechanism governing the oncogenic potential of SOX2 in breast cancer. J Biol Chem 283(26): 17969-17978, 2008. PMID: 18456656. DOI: $10.1074 /$ jbc.M802917200

27 Cox JL, Wilder PJ, Desler M and Rizzino A: Elevating SOX2 levels deleteriously affects the growth of medulloblastoma and glioblastoma cells. PLoS One 7(8): e44087, 2012. PMID: 22937156. DOI: 10.1371/journal.pone.0044087

28 Hussenet T, Dali S, Exinger J, Monga B, Jost B, Dembelé D, Martinet N, Thibault C, Huelsken J, Brambilla E and du Manoir S: SOX2 is an oncogene activated by recurrent 3q26.3 amplifications in human lung squamous cell carcinomas. PLoS One 5(1): e8960, 2010. PMID: 20126410. DOI: 10.1371/journal.pone.0008960

29 Bass AJ, Watanabe H, Mermel CH, Yu S, Perner S, Verhaak RG, Kim SY, Wardwell L, Tamayo P, Gat-Viks I, Ramos AH, Woo MS, Weir BA, Getz G, Beroukhim R, O'Kelly M, Dutt A, Rozenblatt-Rosen O, Dziunycz P, Komisarof J, Chirieac LR, Lafargue CJ, Scheble V, Wilbertz T, Ma C, Rao S, Nakagawa H, Stairs DB, Lin L, Giordano TJ, Wagner P, Minna JD, Gazdar AF, Zhu CQ, Brose MS, Cecconello I, Ribeiro U Jr, Marie SK, Dahl O, Shivdasani RA, Tsao MS, Rubin MA, Wong KK, Regev A, Hahn WC, Beer DG, Rustgi AK and Meyerson M: SOX2 is an amplified lineage-survival oncogene in lung and esophageal 
squamous cell carcinomas. Nat Genet 41(11): 1238-1242, 2009. PMID: 19801978. DOI: 10.1038/ng.465

30 Liu P, Kumar IS, Brown S, Kannappan V, Tawari PE, Tang JZ, Jiang W, Armesilla AL, Darling JL and Wang W: Disulfiram targets cancer stem-like cells and reverses resistance and crossresistance in acquired paclitaxel-resistant triple-negative breast cancer cells. Br J Cancer 109(7): 1876-1885, 2013. PMID: 24008666. DOI: 10.1038/bjc.2013.534

31 Krawczyk N, Hartkopf A, Banys M, Meier-Stiegen F, Staebler A, Wallwiener M, Röhm C, Hoffmann J, Hahn M and Fehm T: Prognostic relevance of induced and spontaneous apoptosis of disseminated tumor cells in primary breast cancer patients. BMC Cancer 14: 394, 2014. PMID: 24894702. DOI: 10.1186/14712407-14-394

32 Walter VP, Taran FA, Wallwiener M, Hahn M, Brucker SY and Hartkopf AD: Simultaneous detection of circulating and disseminated tumor cells in primary breast cancer patients following neoadjuvant chemotherapy. Arch Gynecol Obstet 297(3): 785-790, 2018. PMID: 29380106. DOI: 10.1007/s00404018-4669-9

33 Borgen E, Naume B, Nesland JM, Kvalheim G, Beiske K, Fodstad O, Diel I, Solomayer EF, Theocharous P, Coombes RC, Smith BM, Wunder E, Marolleau JP, Garcia J and Pantel K: Standardization of the immunocytochemical detection of cancer cells in BM and blood: I. establishment of objective criteria for the evaluation of immunostained cells. Cytotherapy 1(5): 377-388, 1999. PMID: 20426539. DOI: $10.1080 / 0032472031000141283$

34 Fehm T, Braun S, Muller V, Janni W, Gebauer G, Marth C, Schindlbeck C, Wallwiener D, Borgen E, Naume B, Pantel K and Solomayer E: A concept for the standardized detection of disseminated tumor cells in bone marrow from patients with primary breast cancer and its clinical implementation. Cancer 107(5): 885-892, 2006. PMID: 16874814. DOI: 10.1002/cncr.22076

35 Lengerke C, Fehm T, Kurth R, Neubauer H, Scheble V, Müller F, Schneider F, Petersen K, Wallwiener D, Kanz L, Fend F, Perner S, Bareiss PM and Staebler A: Expression of the embryonic stem cell marker SOX2 in early-stage breast carcinoma. BMC Cancer 11: 42, 2011. PMID: 21276239. DOI: 10.1186/1471-2407-11-42

36 Pham DL, Scheble V, Bareiss P, Fischer A, Beschorner C, Adam A, Bachmann C, Neubauer H, Boesmueller H, Kanz L, Wallwiener D, Fend F, Lengerke C, Perner S, Fehm T and Staebler A: SOX2 expression and prognostic significance in ovarian carcinoma. Int J Gynecol Pathol 32(4): 358-367, 2013. PMID: 23722508. DOI: 10.1097/PGP.0b013e31826a642b

37 Janni W, Vogl FD, Wiedswang G, Synnestvedt M, Fehm T, Jückstock J, Borgen E, Rack B, Braun S, Sommer H, Solomayer E, Pantel K, Nesland J, Friese K and Naume B: Persistence of disseminated tumor cells in the bone marrow of breast cancer patients predicts increased risk for relapse - a European pooled analysis. Clin Cancer Res 17(9): 2967-2976, 2011. PMID: 21415211. DOI: $10.1158 / 1078-0432 . C C R-10-2515$

38 Mansi JL, Gogas H, Bliss JM, Gazet JC, Berger U and Coombes RC: Outcome of primary-breast-cancer patients with micrometastases: a long-term follow-up study. Lancet 354(9174): 197-202, 1999. PMID: 10421301. DOI: 10.1016/s0140-6736(98)10175-7

39 Luzzi K, Macdonald I, Schmidt E, Kerkvliet N, Morris V, Chambers A and Groom A: Multistep nature of metastatic inefficiency. The American Journal of Pathology 153(3): 865873, 2019. DOI: 10.1016/S0002-9440(10)65628-3
40 Méhes G, Witt A, Kubista E and Ambros PF: Circulating breast cancer cells are frequently apoptotic. Am J Pathol 159(1): 17-20, 2001. PMID: 11438448. DOI: 10.1016/S0002-9440(10)61667-7

41 Guarino M: Epithelial-mesenchymal transition and tumour invasion. Int J Biochem Cell Biol 39(12): 2153-2160, 2007. PMID: 17825600. DOI: 10.1016/j.biocel.2007.07.011

42 Mani SA, Guo W, Liao MJ, Eaton EN, Ayyanan A, Zhou AY, Brooks M, Reinhard F, Zhang CC, Shipitsin M, Campbell LL, Polyak K, Brisken C, Yang J and Weinberg RA: The epithelialmesenchymal transition generates cells with properties of stem cells. Cell 133(4): 704-715, 2008. PMID: 18485877. DOI: 10.1016/j.cell.2008.03.027

43 De Angelis ML, Francescangeli F, La Torre F and Zeuner A: Stem cell plasticity and dormancy in the development of cancer therapy resistance. Front Oncol 9: 626, 2019. PMID: 31355143. DOI: $10.3389 /$ fonc. 2019.00626

44 Piva M, Domenici G, Iriondo O, Rábano M, Simões BM, Comaills V, Barredo I, López-Ruiz JA, Zabalza I, Kypta R and Vivanco Md: Sox 2 promotes tamoxifen resistance in breast cancer cells. EMBO Mol Med 6(1): 66-79, 2014. PMID: 24178749. DOI: $10.1002 / \mathrm{emmm} .201303411$

45 Iturri J, Weber A, Vivanco MD and Toca-Herrera JL: Single-cell probe force studies to identify Sox 2 overexpression-promoted cell adhesion in MCF7 breast cancer cells. Cells 9(4): 935, 2020. PMID: 32290242. DOI: 10.3390/cells9040935

46 Kuo MH, Lee AC, Hsiao SH, Lin SE, Chiu YF, Yang LH, Yu CC, Chiou SH, Huang HN, Ko JC and Chou YT: Cross-talk between SOX2 and TGF $\beta$ signaling regulates EGFR-TKI tolerance and lung cancer dissemination. Cancer Res 80(20): 4426-4438, 2020. PMID: 32816907. DOI: 10.1158/00085472.CAN-19-3228

47 Banys M, Hartkopf AD, Krawczyk N, Kaiser T, Meier-Stiegen F, Fehm T and Neubauer H: Dormancy in breast cancer. Breast Cancer (Dove Med Press) 4: 183-191, 2012. PMID: 24367205. DOI: $10.2147 /$ BCTT.S26431

48 Demicheli R, Abbattista A, Miceli R, Valagussa $\mathrm{P}$ and Bonadonna G: Time distribution of the recurrence risk for breast cancer patients undergoing mastectomy: further support about the concept of tumor dormancy. Breast Cancer Res Treat 41(2): 177-185, 1996. PMID: 8944336. DOI: 10.1007/BF01807163

49 Meng S, Tripathy D, Frenkel EP, Shete S, Naftalis EZ, Huth JF, Beitsch PD, Leitch M, Hoover S, Euhus D, Haley B, Morrison L, Fleming TP, Herlyn D, Terstappen LW, Fehm T, Tucker TF, Lane N, Wang J and Uhr JW: Circulating tumor cells in patients with breast cancer dormancy. Clin Cancer Res 10(24): 81528162, 2004. PMID: 15623589. DOI: 10.1158/1078-0432.CCR04-1110

50 Rodriguez-Pinilla SM, Sarrio D, Moreno-Bueno G, RodriguezGil Y, Martinez MA, Hernandez L, Hardisson D, Reis-Filho JS and Palacios J: Sox2: a possible driver of the basal-like phenotype in sporadic breast cancer. Mod Pathol 20(4): 474-481, 2007. PMID: 17334350. DOI: 10.1038/modpathol.3800760

51 Li X, Lewis MT, Huang J, Gutierrez C, Osborne CK, Wu MF, Hilsenbeck SG, Pavlick A, Zhang X, Chamness GC, Wong H, Rosen J and Chang JC: Intrinsic resistance of tumorigenic breast cancer cells to chemotherapy. J Natl Cancer Inst 100(9): 672679, 2008. PMID: 18445819. DOI: 10.1093/jnci/djn123

52 Liu L, Yang L, Yan W, Zhai J, Pizzo DP, Chu P, Chin AR, Shen $M$, Dong $C$, Ruan $X$, Ren $X$, Somlo $G$ and Wang SE: Chemotherapy induces breast cancer stemness in association 
with dysregulated monocytosis. Clin Cancer Res 24(10): 23702382, 2018. PMID: 29500278. DOI: 10.1158/1078-0432.CCR$17-2545$

53 Fehm T, Krawczyk N, Solomayer EF, Becker-Pergola G, DürrStörzer S, Neubauer H, Seeger H, Staebler A, Wallwiener D and Becker S: ERalpha-status of disseminated tumour cells in bone marrow of primary breast cancer patients. Breast Cancer Res 10(5): R76, 2008. PMID: 18793387. DOI: 10.1186/bcr2143

54 Solomayer EF, Becker S, Pergola-Becker G, Bachmann R, Krämer B, Vogel U, Neubauer H, Wallwiener D, Huober J and Fehm TN: Comparison of HER2 status between primary tumor and disseminated tumor cells in primary breast cancer patients. Breast Cancer Res Treat 98(2): 179-184, 2006. PMID: 16552629. DOI: 10.1007/s10549-005-9147-y

55 Krawczyk N, Banys M, Neubauer H, Solomayer EF, Gall C, Hahn M, Becker S, Bachmann R, Wallwiener D and Fehm T: HER2 status on persistent disseminated tumor cells after adjuvant therapy may differ from initial HER2 status on primary tumor. Anticancer Res 29(10): 4019-4024, 2009. PMID: 19846945.

56 Klein CA: Parallel progression of primary tumours and metastases. Nat Rev Cancer 9(4): 302-312, 2009. PMID: 19308069. DOI: $10.1038 / \mathrm{nrc} 2627$
57 Abd El-Maqsoud NM and Abd El-Rehim DM: Clinicopathologic implications of EpCAM and Sox 2 expression in breast cancer. Clin Breast Cancer 14(1): e1-e9, 2014. PMID: 24201161. DOI: 10.1016/j.clbc.2013.09.006

58 Ben-Porath I, Thomson MW, Carey VJ, Ge R, Bell GW, Regev $A$ and Weinberg RA: An embryonic stem cell-like gene expression signature in poorly differentiated aggressive human tumors. Nat Genet 40(5): 499-507, 2008. PMID: 18443585. DOI: $10.1038 /$ ng.127

59 Huang YH, Luo MH, Ni YB, Tsang JY, Chan SK, Lui PC, Yu $\mathrm{AM}$, Tan PH and Tse GM: Increased SOX2 expression in less differentiated breast carcinomas and their lymph node metastases. Histopathology 64(4): 494-503, 2014. PMID: 24382260. DOI: $10.1111 /$ his.12257
Received March 26, 2021

Revised April 26, 2021

Accepted April 28, 2021 